\title{
Article \\ Detection of Volatiles by HS-SPME-GC/MS and Biological Effect Evaluation of Buddha's Hand Fruit
}

\author{
Sara Vitalini ${ }^{1,2,3} \mathbb{D}^{(D}$, Marcello Iriti ${ }^{1,2,3,4, *(\mathbb{D}}$, Elisa Ovidi ${ }^{5}\left(\mathbb{D}\right.$, Valentina Laghezza Masci ${ }^{5} \mathbb{D}$, Antonio Tiezzi ${ }^{5}$ \\ and Stefania Garzoli ${ }^{6, *(\mathbb{D})}$
}

1 Department of Agricultural and Environmental Sciences, Università degli Studi di Milano, 20133 Milan, Italy; sara.vitalini@unimi.it

2 Phytochem Lab., Department of Agricultural and Environmental Sciences, Università degli Studi di Milano, 20133 Milan, Italy

3 National Interuniversity Consortium of Materials Science and Technology (INSTM), Università degli Studi di Milano, 20133 Milan, Italy

4 Center for Studies on Bioispired Agro-Environmental Technology (BAT Center), Università degli Studi di Milano, 20133 Milan, Italy

5 Department for the Innovation in Biological, Agrofood and Forestal Systems, Tuscia University, 01100 Viterbo, Italy; eovidi@unitus.it (E.O.); laghezzamasci@unitus.it (V.L.M.); antoniot@unitus.it (A.T.)

6 Department of Drug Chemistry and Technology, Sapienza University, 00185 Rome, Italy

* Correspondence: marcello.iriti@unimi.it (M.I.); stefania.garzoli@uniroma1.it (S.G.)

check for

updates

Citation: Vitalini, S.; Iriti, M.; Ovidi,

E.; Laghezza Masci, V.; Tiezzi, A.;

Garzoli, S. Detection of Volatiles by HS-SPME-GC/MS and Biological

Effect Evaluation of Buddha's Hand

Fruit. Molecules 2022, 27, 1666.

https://doi.org/10.3390/

molecules27051666

Academic Editor: Nurhayat

Tabanca

Received: 4 February 2022

Accepted: 1 March 2022

Published: 3 March 2022

Publisher's Note: MDPI stays neutral with regard to jurisdictional claims in published maps and institutional affiliations.

Copyright: (c) 2022 by the authors. Licensee MDPI, Basel, Switzerland. This article is an open access article distributed under the terms and conditions of the Creative Commons Attribution (CC BY) license (https:// creativecommons.org/licenses/by/ $4.0 /)$.

\begin{abstract}
The present work aimed to chemically characterize and evaluate the antiradical power and biological effects of Citrus medica var. sarcodactylus essential oil (EO) and hydrolate (Hy) from exocarp as well as methanol extracts, from both exocarp and mesocarp (EEX and MEX). The whole fresh fruit was also investigated by SPME-GC/MS to describe its volatile composition. EO and Hy were analyzed by GC/MS and HS-GC/MS techniques, respectively. Limonene and $\gamma$-terpinene were found to be the most abundant compounds both in the fresh parts of the fruit and in the EO, while $\alpha$-terpineol and terpinen-4-ol were in the Hy. The extracts were also rich in furan and coumarin derivatives. A good antiradical activity of all samples except Hy was detected both against ABTS + than DPPH. removed up to about 50\%. The antibacterial activity against Bacillus cereus and Escherichia coli was evaluated by microwell dilution method to determine MIC and MBC values. EEX and MEX showed efficacy at very high concentrations against both tested bacteria. The MIC value of EO against $B$. cereus was $0.5 \% v / v$, while Hy was not able to inhibit the bacterial growth at the tested concentrations. Cytotoxicity investigated on the HL60 leukemia cell line by MTT assay provided an $\mathrm{EC}_{50}$ of $1.24 \% v / v$ for EO. Interesting activity of Hy was also observed.
\end{abstract}

Keywords: Citrus medica; fingered citron; separation; chemical analysis; volatile compounds; antibacterial activity; antiradical activity; cytotoxic activity; total flavonoid; total polyphenols

\section{Introduction}

The Citrus species (Rutaceae) is the largest-spread fruit crop in the world, grown in more than 140 countries, of which China, Brazil, and the USA are the top producers [1,2]. They are widely used in the food sector, consumed as a fresh product for their strong fragrance, and in pharmaceutical, medicinal, and cosmetic fields thanks to the beneficial properties of their biologically active constituents [3,4]. In fact, multiple effects such as antioxidant, anti-inflammatory, anticoagulant, and anticancer qualities have been documented. Even essential oils (EOs), usually obtained from the citrus peel, being rich in secondary metabolites [5], are widely used in the food industry for conservation purposes or as additives to enhance the aroma [6], as well as in aromatherapy [7].

Buddha's hand is the common name of $C$. medica var. sarcodactylus (Siebold ex Hoola van Nooten) Swingle (Rutaceae family). Native to northwestern India, it is a small tree with long and irregular branches full of thorns, known to produce peculiarly shaped fruits 
(up to $30 \mathrm{~cm}$ long), segmented into finger-like protrusions, characterized by a white, nonbitter, pulp-free mesocarp (albedo). Externally, the yellowish-orange exocarp (flavedo) is highly fragrant when ripe [8]. Both parts are edible, and are used to prepare desserts, drinks, candies, and sauces [9]. Recently, Buddha's hand fruits have been frequently used in many Japanese restaurants in combination with peaches to serve a fruit salad, and more occasionally as ingredients to formulate crisps and cookies. In general, in the eastern countries where they are known as fingered citrons or as Fo Shou, the fruit is traditionally used in folk medicine. For example, in China, Buddha's hand is appreciated as a tonic, antispasmodic, antiemetic, and expectorant, while in Taiwan it is used for the treatment of stomachache, headache, edema, rheumatism, infectious hepatitis, and arthritis. It is also taken as an adjuvant in the treatment of respiratory tract infections, asthma, and hypertension [10-12]. Some biological activities, including anti-inflammatory, antimicrobial, antioxidant, cytotoxic, and hypoglycemic effects of Buddha's hand extracts or EOs obtained from different parts of the plant (fruits, leaves, peels, roots, stems) have been reported [10,13-17]. Likewise, its chemical composition has been indicated as showing the presence of classes of compounds such as coumarins, flavonoids, phenolic acids, terpenoids, and steroids $[10,18]$.

In our study, we chemically investigated exocarp EO and hydrolate (Hy), as well as exocarp and mesocarp methanol extracts (EEX and MEX), never characterized up to now, with the aim to deepening the knowledge of the secondary metabolites (volatiles and not volatiles) of Buddha's hand, as well as its bioactive potential.

\section{Materials and Methods}

\subsection{Materials}

Ethanol, methanol, 6-hydroxy-2,5,7,8-tetramethylchroman-2-carboxylic acid (Trolox), 2,2-Diphenyl-1-picrylhydrazyl (DPPH), 2,2'-azinobis (3-ethylbenzothiazoline-6-sulfonic acid) diammonium salt (ABTS), potassium persulfate $\left(\mathrm{K}_{2} \mathrm{~S}_{2} \mathrm{O}_{8}\right)$, Lysogeny Broth with Agar and Thiazolyl Blue Tetrazolium Bromide (MTT) were from Merck (Darmstadt, Germany). Gentamicin sulfate was purchased from Biochrome.

\section{Plant Material}

Buddha's hand (Citrus medica var. sarcodactylus) was grown in the Nyon region (Switzerland) and supplied by the Niels Rodin's Citrus Farm. Ripe fruit was harvested in October 2020 and stored in a fridge (about $5^{\circ} \mathrm{C}$ ) until analysis. Before use, it was washed with deionized water and the mesocarp was manually separated from the exocarp.

\subsection{Hydrodistillation}

EO and hydrolate of the Buddha's hand were obtained by subjecting the exocarp (16 g) to hydrodistillation for $3 \mathrm{~h}$ using a clevenger-type apparatus. $\mathrm{EO}$ was dried over anhydrous sodium sulfate and kept in the fridge $\left(4^{\circ} \mathrm{C}\right)$ until use.

\subsection{Extract Peparation}

Exocarp and mesocarp of the Buddha's hand fruit were extracted in agreement with Vitalini et al. [19]. Both tissues were pulverized in liquid nitrogen with a chilled mortar and pestle, then weighed and placed in $\mathrm{MeOH}(3 \mathrm{~mL} / \mathrm{g})$. The mixtures were sonicated and stirred for 10 and $20 \mathrm{~min}$, respectively. Subsequently, each sample was decanted, and the supernatant centrifuged at $10,000 \mathrm{~g}$ for $10 \mathrm{~min}$. The resulting extract was filtered through a $0.22 \mu \mathrm{m}$ filter and combined with that of a second extraction. The solvent was removed in a rotary evaporator (RV 08-VC, IKA, Staufen, Germany) and the residues (EEX and MEX) were stored in glass vials at $4{ }^{\circ} \mathrm{C}$ until use.

\subsection{SPME Sampling of Exocarp and Mesocarp}

To investigate the volatile chemical composition of the Buddha's hand fruit without modification, thin slices of exocarp $(\sim 2 \mathrm{~g})$ and mesocarp $(\sim 2 \mathrm{~g})$ were individually 
placed into a $20 \mathrm{~mL}$ glass vial with PTFE-coated silicone septum. The sampling was performed by SPME technique following Vitalini et al. [20], with some modifications. An SPME device from Supelco (Bellefonte, PA, USA) with $1 \mathrm{~cm}$ fiber coated with 50/30 $\mu \mathrm{m}$ DVB/CAR/PDMS (divinylbenzene/carboxen/polydimethylsiloxane) was used. After an initial conditioning phase of the fiber, at $270{ }^{\circ} \mathrm{C}$ for $20 \mathrm{~min}$, it was exposed to the equilibrated sample headspace for $30 \mathrm{~min}$ at $40^{\circ} \mathrm{C}$ to capture the volatile compounds. After sampling, the SPME fiber was inserted into the GC injector maintained at $250{ }^{\circ} \mathrm{C}$ for the thermal desorption of the adsorbed compounds.

\subsection{HS Sampling of $\mathrm{Hy}$}

To describe the chemical composition of the exocarp Hy vapor phase, a Perkin Elmer Headspace Turbomatrix 40 (Waltham, MA, USA) autosampler connected to GC-MS was used. The operative conditions have been previously described [21]. Briefly, about $2 \mathrm{~mL}$ of Hy was placed in a $20 \mathrm{~mL}$ vial sealed with headspace PTFE-coated silicone rubber septa and cap. The captured components from headspace of Hy were sent to the GC column via a transfer line maintained at a high temperature.

\subsection{GC-MS Analysis of EO and Hy}

To characterize the chemical composition of EO and Hy from exocarp, a Clarus 500 model Perkin Elmer (Waltham, MA, USA) gas chromatograph coupled with a mass spectrometer and equipped with an FID (flame detector ionization) was used. Chromatographic separation was performed using a Varian Factor Four VF-1 capillary column and the gas carrier was He at flow rate of $1.0 \mathrm{~mL} \mathrm{~min}^{-1}$ in constant flow mode. The analytical conditions were applied following [22], with some modifications. For MS detection, an electron impact ionization (EI) system was used at $70 \mathrm{eV}$ in scan mode in the range $35-400 \mathrm{~m} / \mathrm{z}$. The volatile separated compounds were identified by matching their mass spectra with those stored in the Wiley 2.2 and Nist 02 mass spectra libraries database and by comparison of their linear retention indices (LRIs), relative to $\mathrm{C}_{8}-\mathrm{C}_{30} \mathrm{n}$-alkanes analyzed under the same conditions, with those available in the literature. Relative concentrations of individual compounds were expressed as a percentage of the relative peak area to that of the total peak area without the use of an internal standard and any factor correction. All analyses were carried out in triplicate.

\subsection{GC-MS Analysis of EEX and MEX}

Chemical investigation of EEX and MEX was also performed through the same apparatus of Clarus 500. The dried extract and each sample were dissolved in $1 \mathrm{~mL}$ of methanol and the injection volume was $2 \mu \mathrm{L}$. The operative followed conditions have been reported previously [23].

\subsection{Determination of Total Polyphenols}

The total polyphenols of EEX and MEX were determined by the Folin-Ciocalteu method [24]. Briefly, a suitable aliquot of each extract was combined with $50 \mu \mathrm{L}$ of FolinCiocalteau reagent. After $3 \mathrm{~min}, 100 \mu \mathrm{L}$ of a saturated sodium carbonate solution was added and the final volume was made up to $2.5 \mathrm{~mL}$ with distilled water. The solutions were incubated in the dark for $1 \mathrm{~h}$ at room temperature, then their absorbance was read at $725 \mathrm{~nm}$ using a Jenway 6310 spectrophotometer (Keison, Chelmsford, Essex, UK). Tests were performed in triplicate and repeated three times. A calibration curve was prepared with gallic acid as standard at various concentrations $(5-100 \mu \mathrm{g} / \mathrm{mL})$ and the results were expressed as mg gallic acid equivalents (GAE) per $\mathrm{g}$ of fruit part.

\subsection{Determination of Total Flavonoids}

The total flavonoid content of EEX and MEX was determined by the aluminum chloride colorimetric method [25], with some modifications. Briefly, $100 \mu \mathrm{L}$ of each suitably diluted sample was separately mixed with $300 \mu \mathrm{L}$ of methanol, $20 \mu \mathrm{L}$ of $10 \%$ aluminum 
chloride, $20 \mu \mathrm{L}$ of $1 \mathrm{M}$ potassium acetate, and $560 \mu \mathrm{L}$ of distilled water. The final solution was incubated in the dark for $30 \mathrm{~min}$ at room temperature. Then, the absorbance was measured at $420 \mathrm{~nm}$ using a Jenway 6310 spectrophotometer (Keison, Chelmsford, Essex, UK). A calibration curve was prepared with quercetin as standard at various concentrations $(12.5-100 \mu \mathrm{g} / \mathrm{mL})$. The test was performed in triplicate three times, and the results reported as $\mathrm{mg}$ of quercetin equivalents $(\mathrm{QE})$ per $\mathrm{g}$ of fruit part.

\subsection{DPPH Test}

The radical-scavenging capacity of all samples (EO, Hy, EEX and MEX) against DPPH. was assessed, as previously reported by Iriti et al. [26], with some modifications. Briefly, the DPPH. solution was diluted with methanol to obtain $1.00 \pm 0.03$ absorbance units at $517 \mathrm{~nm}$. Then, $10 \mu \mathrm{L}$ of each EO were added to $1990 \mu \mathrm{L}$ of this solution and vortexed. After a reaction time of $30 \mathrm{~min}$ in the dark at room temperature, the decrease in absorbance was read using a Jenway 6310 spectrophotometer (Keison, Chelmsford, Essex, UK) and expressed as RSA (radical scavenging activity) $\%=\left[\left(\mathrm{ABS}_{\text {control }}-\mathrm{ABS}_{\text {sample }}\right) / \mathrm{ABS}_{\text {control }}\right] \times 100 . \mathrm{A} \mathrm{DPPH}$. solution without a sample was used as control. Tests were performed in triplicate.

\subsection{ABTS Test}

The ABTS + radical cation-scavenging activity was determined following Vitalini et al. [24]. The ABTS + radical cation was produced by reacting ABTS $7 \mathrm{mM}$ with potassium persulfate $2.45 \mathrm{mM}$ and keeping the mixture in the dark at room temperature for at least $6 \mathrm{~h}$ before use. Then, the ABTS + solution was diluted with ethanol to an absorbance of $0.7( \pm 0.02)$ at $734 \mathrm{~nm}$ and equilibrated at $30{ }^{\circ} \mathrm{C}$. Then, $1 \mathrm{~mL}$ of this solution was mixed for $30 \mathrm{~s}$ with $10 \mu \mathrm{L}$ of each sample (EO, Hy, EEX and MEX). Ethanol and a standard solution of the synthetic antioxidant 6-hydroxy-2,5,7,8-tetramethychroman-2-carboxylic acid (Trolox) were used as negative and positive controls, respectively. Their absorbance was read at $734 \mathrm{~nm}$, at room temperature, $20 \mathrm{~s}$ after the end of the mixing using a Jenway 6310 spectrophotometer (Keison, Chelmsford, Essex, UK). Tests were performed in triplicate. The inhibition percentage was calculated, and the results expressed as radical scavenging activity (RSA) determined using the following equation: RSA (radical scavenging activity)\% $=\left[\left(\mathrm{ABS}_{\text {control }}-\mathrm{ABS}_{\text {sample }}\right) / \mathrm{ABS}_{\text {control }}\right] \times 100$.

\subsection{Antibacterial Activity}

The antibacterial activity of EEX, MEX, EO, and Hy were defined by the Minimal Inhibitory Concentration (MIC) and the Minimal Bactericidal Concentration (MBC).

Gram-negative (Escherichia coli ATCC 25922) and Gram-positive (Bacillus cereus ATCC 10876) bacteria were obtained by growing cultures from the collection of the Plant $\mathrm{Cy}$ tology and Biotechnology Laboratory (Tuscia University) and grown at $37^{\circ} \mathrm{C}$ and $26^{\circ} \mathrm{C}$, respectively, in Lysogeny Broth (LB) agar.

The microwell dilution method was used to determine Minimum Inhibitory Concentration (MIC), as reported by Garzoli et al. in 2021 [27]. All the matrices were diluted twelve times in LB broth (from 10 to $4.9 \times 10^{-3} \mathrm{mg} / \mathrm{mL}$ and $1 \%$ to $5 \times 10^{-4 \%}$ for extracts and EOs, respectively), DMSO controls, growth controls without treatments, and sterility controls without bacteria were added to 96-microwell plates. As positive controls, gentamicin dilutions $(100 \mu \mathrm{g} / \mathrm{mL}$ to $0.049 \mu \mathrm{g} / \mathrm{mL})$ were used. In each well, a bacteria suspension $\left(10^{6} \mathrm{CFU} / \mathrm{mL}\right)$ was added, except to the sterility control, and after $24 \mathrm{~h}, 20 \mu \mathrm{L}$ of 3-(4,5-dimethylthiazol-2-yl)-2,5-diphenyltetrazolium bromide (200 $\mu \mathrm{g} / \mathrm{mL}, \mathrm{MTT})$ was added to determine the bacterial growth.

To determine the Minimum Bactericidal Concentration (MBC), defined as the lowest concentration of an antibacterial agent required to kill a bacterium over a fixed period, $10 \mu \mathrm{L}$ of the last four dilutions from the microwell dilution method in which no bacteria growth was observed were plated on LB agar following $24 \mathrm{~h}$ of incubation. The assay was carried out in triplicate. To define if the antibacterial activities of the tested samples were 
bactericidal or bacteriostatic, the ratio $\mathrm{MBC} / \mathrm{MIC}$ of each sample was calculated and when the obtained value was $<4$, a bactericidal activity was defined.

\subsection{Cell Culturing and Cytotoxicity Test (MTT)}

The cellular metabolic activity, as an indicator of cell viability of HL60 cells treated with extracts, EO, and related Hy of C. medica, was investigated by thiazolyl blue tetrazolium bromide assay (MTT assay), both in a dose- and time-dependent manner. The cells were maintained in a $75 \mathrm{~cm}^{2}$ flask containing RPMI 1640 culture medium supplemented with $10 \%$ of FBS (fetal bovine serum), $1 \%$ glutamine and $1 \%$ penicillin/streptomycin, and maintained in an incubator to control temperature and $\% \mathrm{CO}_{2}\left(37^{\circ} \mathrm{C}\right.$ and $\left.5 \% \mathrm{CO}_{2}\right)$. Cells were seeded $\left(2 \times 10^{4}\right.$ cells/well) in a 96-well plate $24 \mathrm{~h}$ before being treated. EO was dissolved in DMSO $(50 \% \mathrm{v} / \mathrm{v})$. Twelve two-fold diluted concentrations were applied from 0.5 to $0.01 \mathrm{mg} / \mathrm{mL}$ for extracts, from $1 \times 10^{-1 \%}$ to $2 \times 10^{-4 \%} v / v$ for the EO and from $50 \%$ to $1 \times 10^{-1 \%} v / v$ for the HY; the DMSO $(0.05 \%$ final concentration $)$ and $\mathrm{ddH}_{2} \mathrm{O}$ were used as solvent controls. As positive control, vinblastine sulfate (Merck KGaA, Darmstadt, Germany) was used. After treatments for $72 \mathrm{~h}$, the medium has been removed and MTT solution $(0.5 \mathrm{mg} / \mathrm{mL})$ was added. Incubation was carried out for $3 \mathrm{~h}$ in a dark condition at $37^{\circ} \mathrm{C}$ and, after formazan crystals solubilization by DMSO, the absorbance was read by a Tecan Sunrise ${ }^{\mathrm{TM}}$ $\mathrm{UV}$-vis spectrophotometer at $595 \mathrm{~nm}$. The obtained values were used to calculate the cell viability percentage (AAT Bioquest EC50 Calculator) [28], and to obtain the concentration at which the treatments exerted half of the maximal response values (EC50). Means $\pm \mathrm{SD}$ were calculated by repeating the assay three times.

\subsection{Statistical Analysis}

All data were expressed as means \pm standard deviation (SD). Statistical analyses were preformed using a one-way ANOVA test with a Stat-Plus software (AnalystSoft VC 2009), with the threshold of significance set at $p<0.05$.

\section{Results}

\subsection{Vapor Phase Chemical Composition}

SPME-GC/MS analysis was performed to describe the volatile composition of fresh Buddha's hand exocarp and mesocarp. In total, eighteen compounds were identified and listed in Table 1. In general, the monoterpene content largely prevailed over the sesquiterpene content in both the exocarp and mesocarp, and limonene $(75.8 \% ; 76.2 \%)$ and $\gamma$-terpinene $(16.5 \% ; 15.0 \%)$ were the most abundant compounds. $\beta$-Pinene $(2.5 \% ; 2.4 \%)$, $\alpha$-pinene $(1.6 \% ; 1.4 \%)$, and cis- $\beta$-ocimene $(1.2 ; 1.1 \%)$ were also present with lower and comparable relative percentages. Small qualitative differences were found between the two matrices; $\beta$-thujene $(0.2 \%)$ and $\alpha$-farnesene $(0.2 \%)$ were present only in the exocarp while carveol $(0.1 \%)$ and $\alpha$-citral $(0.1 \%)$ were present only in the mesocarp.

\subsection{EEX and MEX Chemical Composition}

The GC-MS analysis of the extracts allowed us to identify twelve compounds whose relative percentages are summarized in Table 2. Derivatives of furan were the main class of detected compounds, among which, 5-HMF was the main exponent with relative percentages of $14.7 \%$ and $24.8 \%$ in the EEX and in the MEX, respectively. 2-Furanmethanol $(3.9 \% ; 6.7 \%)$ and furaneol $(3.1 \% ; 3.6 \%)$ were also present in both extracts. Coumarin, 5,7-dimethoxy $(50.6 \%)$ was the most abundant compound in the EEX followed by 2-pyrone $(23.4 \%)$. On the contrary, 2-pyrone (33.1\%) and 2,3-butanediol $(23.7 \%)$ were the main component non-furanoic derivatives, present in MEX. 
Table 1. Chemical composition (percentage mean value \pm standard deviation) of exocarp and mesocarp.

\begin{tabular}{|c|c|c|c|c|c|}
\hline No. & Component $^{1}$ & LRI $^{2}$ & LRI $^{3}$ & Exocarp ${ }^{4}(\%)$ & Mesocarp 5 (\%) \\
\hline 1 & $\alpha$-thujene & 923 & 925 & $0.5 \pm 0.02$ & $0.4 \pm 0.03$ \\
\hline 2 & $\alpha$-pinene & 941 & 943 & $1.6 \pm 0.02$ & $1.4 \pm 0.01$ \\
\hline 3 & $\beta$-thujene & 966 & 968 & $0.2 \pm 0.01$ & - \\
\hline 4 & $\beta$-pinene & 980 & 986 & $2.5 \pm 0.02$ & $2.4 \pm 0.02$ \\
\hline 5 & $\alpha$-phellandrene & 998 & 996 & - & $\operatorname{tr}$ \\
\hline 6 & p-cymene & 1020 & 1016 & $0.2 \pm 0.02$ & $0.7 \pm 0.03$ \\
\hline 7 & limonene & 1024 & 1023 & $75.8 \pm 0.02$ & $76.2 \pm 0.02$ \\
\hline 8 & cis- $\beta$-ocimene & 1035 & 1032 & $1.2 \pm 0.02$ & $1.1 \pm 0.02$ \\
\hline 9 & $\gamma$-terpinene & 1057 & 1054 & $16.5 \pm 0.02$ & $15.0 \pm 0.02$ \\
\hline 10 & $\alpha$-terpinolene & 1081 & 1078 & $0.2 \pm 0.02$ & $0.6 \pm 0.02$ \\
\hline 11 & $\alpha$-terpineol & 1185 & 1183 & $0.1 \pm 0.01$ & $0.4 \pm 0.02$ \\
\hline 12 & carveol & 1205 & 1201 & - & $0.1 \pm 0.00$ \\
\hline 13 & 4-terpinenyl acetate & 1282 & 1286 & $0.5 \pm 0.02$ & $0.1 \pm 0.02$ \\
\hline 14 & $\alpha$-citral & 1285 & 1287 & - & $0.1 \pm 0.00$ \\
\hline 15 & $\alpha$-bergamotene & 1433 & 1431 & $0.3 \pm 0.02$ & $0.6 \pm 0.02$ \\
\hline 16 & $\alpha$-himachalene & 1451 & 1447 & $0.1 \pm 0.02$ & $0.6 \pm 0.02$ \\
\hline 17 & $\gamma$-gurjunene & 1482 & 1479 & - & $\operatorname{tr}$ \\
\hline \multirow[t]{5}{*}{18} & $\alpha$-farnesene & 1510 & 1506 & $0.2 \pm 0.02$ & - \\
\hline & SUM & & & 99.9 & 99.7 \\
\hline & Monoterpene hydrocarbons & & & 98.7 & 97.8 \\
\hline & Oxygenated monoterpenes & & & 0.6 & 0.7 \\
\hline & Sesquiterpene hydrocarbons & & & 0.6 & 1.2 \\
\hline
\end{tabular}

${ }^{1}$ The components are reported according to their elution order on apolar column; ${ }^{2}$, Linear Retention Indices measured on apolar column; ${ }^{3}$, Linear Retention Indices from literature; Exocarp ${ }^{4}$, percentage mean values of exocarp components (\%); Mesocarp ${ }^{5}$, percentage mean values of mesocarp components; -, not detected; tr, traces (mean value $<0.1 \%$ ).

Table 2. Chemical composition (percentage mean value \pm standard deviation) of exocarp and mesocarp extracts.

\begin{tabular}{|c|c|c|c|c|c|}
\hline No. & Component $^{1}$ & LRI $^{2}$ & LRI $^{3}$ & $\operatorname{EEX}^{4}(\%)$ & $\operatorname{MEX}^{5}(\%)$ \\
\hline 1 & 2,3-butanediol & 785 & 789 & - & $23.7 \pm 0.02$ \\
\hline 2 & furfural & 796 & 794 & $1.8 \pm 0.01$ & $3.9 \pm 0.03$ \\
\hline 3 & 2(3H)-furanone, 5-methyl- & 832 & 830 & $0.9 \pm 0.02$ & - \\
\hline 4 & 2-furanmethanol & 860 & 856 & $3.9 \pm 0.02$ & $6.7 \pm 0.04$ \\
\hline 5 & furfural, 5-methyl- & 970 & 965 & - & $1.9 \pm 0.03$ \\
\hline 6 & furaneol & 1052 & 1055 & $3.1 \pm 0.02$ & $3.6 \pm 0.01$ \\
\hline 7 & 2-pyrone & 1130 & 1134 & $23.4 \pm 0.02$ & $33.1 \pm 0.01$ \\
\hline 8 & 5-HMF & 1210 & 1208 & $14.7 \pm 0.02$ & $24.8 \pm 0.02$ \\
\hline 9 & (E)- $\beta$-farnesene & 1461 & * & $1.0 \pm 0.02$ & - \\
\hline 10 & $(\mathrm{Z}, \mathrm{E})-\alpha$-farnesene & 1480 & 1475 & $0.6 \pm 0.02$ & - \\
\hline 11 & coumarin, 5,7-dimethoxy & 1920 & 1916 & $50.6 \pm 0.02$ & $0.7 \pm 0.02$ \\
\hline 12 & $\begin{array}{c}\text { hexadecanoic acid } \\
\text { SUM }\end{array}$ & 1960 & 1954 & $\begin{array}{c}- \\
100.0\end{array}$ & $\begin{array}{c}1.6 \pm 0.02 \\
100.0\end{array}$ \\
\hline
\end{tabular}

${ }^{1}$ The components are reported according to their elution order on apolar column; ${ }^{2}$, Linear Retention Indices measured on apolar column; ${ }^{3}$, Linear Retention Indices from literature; ${ }^{*}$, LRI not available; EEX ${ }^{4}$, percentage mean values of exocarp components extract (\%); $\mathrm{MEX}^{5}$, percentage mean values of components mesocarp; -, not detected; $\mathrm{tr}$, traces (mean value $<0.1 \%$ ).

\subsection{EO and Hy Chemical Composition}

The content of volatile compounds for EO analysis was determined by GC-MS technique and by HS-GC/MS technique for Hy headspace analysis. In total, twenty-nine compounds were detected and listed in Table 3. The chemical composition of EO was found to be rich in monoterpene hydrocarbons $(91.3 \%)$ followed by oxygenated monoterpenes $(4.5 \%)$ and sesquiterpene hydrocarbons (3.9\%). Conversely, Hy was rich in oxygenated monoterpenes $(89.6 \%)$, while sesquiterpene hydrocarbons were absent. 
Table 3. Chemical composition (percentage mean value \pm standard deviation) of EO and Hy.

\begin{tabular}{|c|c|c|c|c|c|}
\hline No. & Component $^{1}$ & LRI $^{2}$ & LRI $^{3}$ & $\mathrm{EO}^{4}(\%)$ & $\mathrm{Hy}^{5}(\%)$ \\
\hline 1 & $\alpha$-thujene & 923 & 925 & $0.2 \pm 0.02$ & - \\
\hline 2 & $\alpha$-pinene & 941 & 943 & $0.6 \pm 0.03$ & - \\
\hline 3 & $\beta$-thujene & 966 & 968 & $0.1 \pm 0.00$ & - \\
\hline 4 & $\beta$-myrcene & 983 & 980 & $0.9 \pm 0.01$ & - \\
\hline 5 & $\beta$-pinene & 980 & 986 & $0.8 \pm 0.01$ & - \\
\hline 6 & $\alpha$-phellandrene & 998 & 996 & $\operatorname{tr}$ & - \\
\hline 7 & $(+)$-4-carene & 1005 & 1001 & $0.2 \pm 0.02$ & - \\
\hline 8 & $p$-cymene & 1020 & 1016 & $1.6 \pm 0.02$ & $0.4 \pm 0.01$ \\
\hline 9 & limonene & 1024 & 1023 & $66.9 \pm 0.02$ & $3.2 \pm 0.02$ \\
\hline 10 & $\beta$-terpinene & 1040 & 1036 & - & $1.0 \pm 0.01$ \\
\hline 11 & $\gamma$-terpinene & 1057 & 1054 & $20.0 \pm 0.03$ & - \\
\hline 12 & linalol & 1091 & 1088 & - & $5.7 \pm 0.03$ \\
\hline 13 & R-(+)-citronellal & 1158 & 1152 & $0.1 \pm 0.02$ & - \\
\hline 14 & terpinen-4-ol & 1186 & 1182 & $0.5 \pm 0.02$ & $21.6 \pm 0.02$ \\
\hline 15 & $\alpha$-terpineol & 1185 & 1193 & $1.2 \pm 0.01$ & $44.7 \pm 0.01$ \\
\hline 16 & cis-geraniol & 1228 & 1231 & $0.2 \pm 0.02$ & $7.2 \pm 0.01$ \\
\hline 17 & $\beta$-citral & 1238 & 1242 & $0.9 \pm 0.05$ & $5.8 \pm 0.03$ \\
\hline 18 & $\alpha$-citral & 1285 & 1287 & $1.3 \pm 0.01$ & $8.0 \pm 0.02$ \\
\hline 19 & thymol & 1308 & 1310 & - & $1.9 \pm 0.02$ \\
\hline 20 & piperitenone & 1316 & 1315 & - & $0.4 \pm 0.01$ \\
\hline 21 & nerol acetate & 1362 & 1365 & $0.2 \pm 0.02$ & - \\
\hline 22 & geranyl acetate & 1381 & 1380 & $0.1 \pm 0.02$ & - \\
\hline 23 & $\beta$-caryophyllene & 1455 & 1457 & $1.7 \pm 0.02$ & - \\
\hline 24 & humulene & 1470 & 1473 & $0.1 \pm 0.00$ & - \\
\hline 25 & germacrene D & 1491 & 1489 & $0.6 \pm 0.01$ & - \\
\hline 26 & $\beta$-bisabolene & 1505 & 1501 & $1.2 \pm 0.01$ & - \\
\hline 27 & bicyclogermacrene & 1510 & * & $0.1 \pm 0.00$ & - \\
\hline 28 & $\delta$-cadinene & 1532 & 1530 & $0.1 \pm 0.00$ & - \\
\hline \multirow[t]{5}{*}{29} & $\alpha$-bisabolol & 1670 & 1668 & $0.1 \pm 0.02$ & - \\
\hline & SUM & & & 99.7 & 99.9 \\
\hline & Monoterpene hydrocarbons & & & 91.3 & 10.3 \\
\hline & Oxygenated monoterpenes & & & 4.5 & 89.6 \\
\hline & Sesquiterpene hydrocarbons & & & 3.9 & - \\
\hline
\end{tabular}

${ }^{1}$ The components are reported according to their elution order on apolar column; ${ }^{2}$, Linear Retention Indices measured on apolar column; ${ }^{3}$, Linear Retention indices from literature; ${ }^{*}$, LRI not available; $\mathrm{EO}^{4}$, percentage mean values of exocarp components (\%); $\mathrm{Hy}^{5}$, percentage mean values of exocarp components (\%); -, not detected; tr, traces (mean value $<0.1 \%$ ).

Qualitative and quantitative differences between the chemical composition of $\mathrm{EO}$ and HY were found. In detail, the volatile profile of $\mathrm{EO}$ was characterized by limonene $(66.9 \%)$ and $\gamma$-terpinene $(20.0 \%)$ as the most abundant compounds, while $\alpha$-terpineol $(44.7 \%)$ and terpinen-4-ol (21.6\%) were in the Hy.

Furthermore, several minor monoterpene components, such as $\alpha$-thujene $(0.2 \%)$, $\alpha$-pinene $(0.6 \%), \beta$-thujene $(0.1 \%), \beta$-myrcene $(0.9 \%), \beta$-pinene $(0.8 \%),(+)$-4-carene $(0.2 \%)$, $\mathrm{R}-(+)$-citronellal $(0.1 \%)$, nerol acetate $(0.2 \%)$, and geranyl acetate $(0.1 \%)$ found in the EO were missing in the Hy. Instead, other compounds such as $\beta$-terpinene (1.0\%), linalol (5.7\%), thymol $(1.9 \%)$, and piperitenone $(0.4 \%)$ were detected only in the HY.

\subsection{Content of Polyphenols and Flavonoids}

Table 4 shows the total polyphenol and flavonoid content of the methanolic extracts obtained from the Buddha's hand exocarp and mesocarp. Both parts possessed a similar content of the two types of compounds. Nevertheless, as expected, EEX was found to be richer in both polyphenols and flavonoids than MEX. Their quantity in the EEX was about 1.5 times higher. 
Table 4. Total polyphenols and flavonoids of EEX and MEX.

\begin{tabular}{ccc}
\hline Samples & $\begin{array}{c}\text { Total Polyphenols } \\
\text { (mg GAE/g Fruit Part) }\end{array}$ & $\begin{array}{c}\text { Total Flavonoids } \\
\text { (mg QE/g Fruit Part) }\end{array}$ \\
\hline EEX & $2.52 \pm 0.07$ & $2.20 \pm 0.26$ \\
\hline MEX & $1.74 \pm 0.02$ & $1.50 \pm 0.06$ \\
\hline
\end{tabular}

EEX, exocarp extract; MEX, mesocarp extract.

\subsection{Antiradical Activity}

Table 5 reports the activity values of all samples (EEX, MEX, EO and Hy) against the radicals ABTS + and DPPH - As for their ability to scavenge ABTS-+, EEX, MEX and EO showed a similar efficacy, removing it by more than $50 \%$. Hy was essentially inactive. The same trend was observed towards DPPH. by all samples except EO: it was able to inhibit this stable radical by only $26.4 \%$.

Table 5. Antiradical power of EEX and MEX.

\begin{tabular}{ccc}
\hline Samples & $\begin{array}{c}\text { ABTS } \\
\text { RSA (\%) }\end{array}$ & $\begin{array}{c}\text { DPPH } \\
\text { RSA (\%) }\end{array}$ \\
\hline EEX & $55.8 \pm 5.4$ & $55.7 \pm 1.20$ \\
\hline MEX & $52.0 \pm 0.4$ & $46.7 \pm 0.82$ \\
\hline EO & $54.1 \pm 0.2$ & $26.4 \pm 0.74$ \\
\hline Hy & $3.1 \pm 0.2$ & $2.5 \pm 0.3$ \\
\hline
\end{tabular}

EEX, exocarp extract; MEX, mesocarp extract; EO, exocarp essential oil.

\subsection{EO, Hy, EEX and MEX Antibacterial Activity}

The in vitro antibacterial activities of $C$. medica EEX, MEX, EO, Hy were tested using B. cereus and E. coli by defining MIC and MBC values. In Table 6, the obtained results for the extracts treatments are summarized. For B. cereus, EEX, MIC, and MBC values (2.5 and $5 \mathrm{mg} / \mathrm{mL}$, respectively) were lower than MEX, MIC, and MBC values $(10 \mathrm{mg} / \mathrm{mL})$. For E. coli, the activity of the tested matrices was lower than the results for B. cereus (MIC values were $10 \mathrm{mg} / \mathrm{mL}$ for both extracts; $\mathrm{MBC}$ values were not attained at the tested concentrations).

Table 6. Antibacterial activity of EEX and MEX.

\begin{tabular}{ccccccc}
\hline & \multicolumn{2}{c}{ EEX } & \multicolumn{3}{c}{ MEX } \\
\hline Strains & MIC $^{\mathbf{1}}$ & MBC $^{2}$ & $\begin{array}{c}\text { MBC/MIC } \\
\text { Ratio }\end{array}$ & MIC $^{\mathbf{1}}$ & MBC $^{2}$ & $\begin{array}{c}\text { MBC/MIC } \\
\text { Ratio }\end{array}$ \\
\hline $\begin{array}{c}\text { B. cereus } \\
\text { E. coli }\end{array}$ & 2.5 & 5.0 & 2.0 & 10.0 & 10.0 & 1.0 \\
10.0 & na & - & 10.0 & na & - \\
\hline
\end{tabular}

${ }^{1}$ Minimal Inhibitory Concentration and ${ }^{2}$ Minimal Bactericidal Concentration expressed in $\mathrm{mg} / \mathrm{mL}$. EEX, exocarp extract; MEX, mesocarp extract.

In Table 7, the MIC value of $\mathrm{EO}$ was $0.5 \%$ and $\mathrm{MBC}$ value was $1.0 \%$ against $B$. cereus. For E. coli, MIC and MBC values were not attained. On the contrary, Hy did not possess activity at the tested concentration against both bacteria. MIC/MBC ratios defined that the active samples possessed bactericidal properties.

\subsection{Cytotoxicity Test on HL60 Cell Line}

The cytotoxic activity of Buddha's hand was evaluated for the EEX and MEX samples expressing the obtained $\mathrm{EC}_{50}$ values in $\mathrm{mg} / \mathrm{mL}$, and for $\mathrm{EO}$ and Hy samples expressing the obtained $\mathrm{EC}_{50}$ values in $\% v / v$ by using the MTT assay on the HL60 cell line. Treatments were carried out for $72 \mathrm{~h}$ and results are reported in Tables 8 and 9. The $\mathrm{EC}_{50}$ value was 
$1.76 \mathrm{mg} / \mathrm{mL}$ for $\mathrm{EEX}$, while the $\mathrm{EC}_{50}$ was not attained for MEX by the used concentration range. $\mathrm{EO}$ and Hy showed an $\mathrm{EC}_{50}$ of 1.24 and $2.97 \% v / v$, respectively.

Table 7. Antibacterial activity of EO and HY.

\begin{tabular}{ccccccc}
\hline & \multicolumn{3}{c}{ EO } & \multicolumn{3}{c}{ Hy } \\
\hline Strains & MIC $^{\mathbf{1}}$ & MBC $^{2}$ & $\begin{array}{c}\text { MBC/MIC } \\
\text { Ratio }\end{array}$ & MIC $^{\mathbf{1}}$ & MBC $^{2}$ & $\begin{array}{c}\text { MBC/MIC } \\
\text { Ratio }\end{array}$ \\
\hline $\begin{array}{c}\text { B. cereus } \\
\text { E. coli }\end{array}$ & 0.5 & 1.0 & 2.0 & na & - & - \\
na & - & - & na & - & -
\end{tabular}

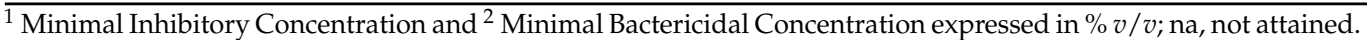

Table 8. Cytotoxic activity of EEX and MEX on HL60 cell line for $72 \mathrm{~h}$.

\begin{tabular}{cc}
\hline Samples & EC $_{\mathbf{5 0}} \pm$ SD \\
\hline EEX & $1.76 \pm 0.32$ \\
MEX & na
\end{tabular}

Effective Concentration $\left(\mathrm{EC}_{50}\right.$ value $\pm \mathrm{SD}$ ) are expressed in $\mathrm{mg} / \mathrm{mL}$. EEX, exocarp extract; MEX, mesocarp extract.

Table 9. Cytotoxic activity of EO and Hy on HL60 cell line for $72 \mathrm{~h}$.

\begin{tabular}{cl}
\hline Samples & EC $_{\mathbf{5 0}} \pm$ SD \\
\hline EO & $1.24 \pm 0.42$ \\
Hy & $2.97 \pm 0.07$
\end{tabular}

Effective Concentration $\left(\mathrm{EC}_{50}\right.$ value $\pm \mathrm{SD}$ ) are expressed in $\% v / v$ for $\mathrm{EO}$ and Hy. EO, exocarp essential oil; Hy, exocarp hydrolate.

\section{Discussion}

In this report, the volatile chemical composition of the fresh parts (exocarp and mesocarp) and of the respective methanol extracts, as well as of the hydrodistillation products (EO and Hy) obtained from the exocarp of C. medica var. sarcodactylus, grown in Switzerland, were described. The volatile profile of unmodified Buddha's hand fruit, obtained by SPME-GC/MS analysis, highlighted an absolute prevalence of terpene hydrocarbons both in the exocarp and in the mesocarp with limonene and $\gamma$-terpinene as major compounds, according to Song et al. [29], who also considered this sampling technique as the most efficient to capture volatiles such as terpenes from this fresh matrix. Furthermore, it was also used to reveal the variation of the chemical composition of Buddha's hand species due to the pickling processes [30].

There are a limited number of works on the chemical composition of EOs from Buddha's hand fruit grown in other countries. In our study, exocarp EO was found to be rich in limonene and $\gamma$-terpinene, according to some previous studies [14,15,31-34]. Otherwise, other papers reported a lower content of these components [16] or, instead of $\gamma$-terpinene as the second major constituent, the presence of other molecules such as geraniol [11], $\alpha$-pinene [35] and $\beta$-caryophyllene [36]. In general, such changes in the composition of EOs could be attributed to various factors, including the extraction or isolation method, conditions of analysis, geographic origin, climatic region conditions, and genetic variability [37-41]. With regard to Buddha's hand EO, the stage of maturity is also a predominant factor. Wu et al. [16] reported that, in the mature phases, the quantity of monoterpenic hydrocarbons is higher, while the quantity of sesquiterpene hydrocarbons and oxygenated compounds is reduced.

To the best of our knowledge, this is the first study dealing with the chemical characterization of the EEX and MEX and of the Hy by GC/MS and HS-GC/MS techniques, respectively. The findings showed that extracts were rich in furan and coumarin compounds, while in the Hy, oxygenated monoterpenes dominated.

In addition to these volatiles, the presence of polyphenols including flavonoids in both EEX and MEX could explain the biological activities recorded in this study. Polyphe- 
nols are widely recognized to be strong antioxidants, with the ability to neutralize free radicals [42]. Many phenolic compounds may also exhibit significant antibacterial activity involving some sites of action at the cellular level [43]. Previously, the antioxidant activity of Buddha's hand $\mathrm{EO}$ has been investigated by obtaining variable values in relation to various considered factors, such as isolation methods, heat stress, or maturity stage, as well as the involved target $[16,37,44]$. Our data were in line with those of Wu et al. [16], who, among the test samples, reported the lowest scavenging ability against DPPH. for mature Buddha's hand fruit. Nevertheless, the results of other works showed different DPPH radical-scavenging activities, with both lower and higher inhibition percentages [45,46]. The same goes for the activity detected towards ABTS + $[45,47]$. The discrepancy found could be explained by many factors, including those listed above, but also by different chemical compositions of the same Citrus species due to varied growing areas and climatic conditions. A large variety of EOs also possess the capacity to inhibit microbiological growth, and their potential applications are always the subject of research [48-50]. In our study, the antibacterial activity of the EEX, MEX, EO, and Hy of Buddha's hand were investigated by the determination of MIC and MBC values against B. cereus and E. coli. All the samples were more active against B. cereus than E. coli; for the latter, MIC values were not attained at the tested concentrations except for the samples EEX and MEX, for which they were determined, although at a high concentration. Against B. cereus, EEX was more active than MEX. In particular, the highest activity recorded in EEX could be due to its major compound, coumarin, 5,7-dimethoxy, according to what was reported by Sahoo et al. [51]. EO had low a MIC value, showing high antibacterial activity. Previous studies have reported the antibacterial activity of Citrus medica L. var. sarcodactylus EO against food-borne bacteria, and various human multi-drug-resistant pathogenic bacteria [17,31,52]. Lou et al. [46] reported that the nano-emulsified EO showed an increased activity on $S$. aureus and on E. coli inhibiting the bacteria biofilm formation in tofu. Furthermore, the main constituents of EO, such as limonene and $\gamma$-terpinene, have been shown to have antimicrobial activity [53-56].

EEX was also found to have a cytotoxic effect against HL60 human cell line. This power could be attributed to its chemical composition. In fact, coumarins and coumarin derivatives possess a broad range of biological activities, including anticancer activity by apoptosis induction, cell cycle arrest, and several other mechanisms of action $[57,58]$. The 5-HMF compound has also been reported to have cytotoxic activity against HCT-8, A549, and SGC-7901 cell lines [59], as well as exert antioxidant activity [60]. In our investigation of the extracts, we also detected the 2-pyrone compound with considerable percentage values; previous studies have demonstrated both the antimicrobial and cytotoxic power of 2-pyrone derivatives [61].

In this work, the chosen techniques to investigate the volatile chemical composition and to study the biological activities, represent the first screening to be used [62-65]. The results obtained by EO and Hy MTT assay expressed an interesting cytotoxic activity. Buddha's hand EO and limonene, its most abundant component, were shown to possess cancer-specific activity when tested against the skin melanoma A375 cells and normal skin cells [66]. Concerning Hy cytotoxicity, $\mathrm{EC}_{50}$ results were quite low, which revealed a very good activity. In our investigation, Hy was rich in $\alpha$-terpineol and terpinen-4-ol, whose potential anticancer action, through cycle inhibition and apoptosis induction, has been demonstrated $[67,68]$. These compounds could explain the Hy cytotoxicity that has, until now, never been investigated.

\section{Conclusions}

In this multidisciplinary study, the chemical volatile composition of Buddha's hand fresh parts, exocarp EO and Hy, and methanol extracts from exocarp and mesocarp were characterized by HS-SPME-GC/MS techniques. Furthermore, the content of polyphenols and flavonoids as well as antioxidant power and antibacterial and cytotoxic action were evaluated. The findings were particularly interesting regarding the cytotoxic effect against 
the HL60 human cell line shown both by the EEX and MEX, and by Hy, investigated for the first time. The obtained data could be useful as additional information on the phytochemical and biological properties of this fruit and, considering the large pool of bioactive detected compounds, highlight its functional benefits. Furthermore, the secondary identified metabolites could represent an environmentally friendly platform to produce new nutraceuticals usable in food, or healthy diets.

Author Contributions: Conceptualization, S.V., S.G.; methodology, S.V., V.L.M. and S.G.; writingoriginal draft preparation, S.V., E.O. and S.G.; writing-review and editing, S.V., E.O. and S.G.; data curation, S.V., E.O., V.L.M. and S.G.; funding, M.I., A.T. and S.G. All authors have read and agreed to the published version of the manuscript.

Funding: This research received no external funding.

Institutional Review Board Statement: Not applicable.

Informed Consent Statement: Not applicable.

Data Availability Statement: All generated data are included in this article.

Acknowledgments: The authors are thankful to Niels Rodin's Citrus Farm, Switzerland, for providing Citrus medica var. sarcodactylus species.

Conflicts of Interest: The authors declare no conflict of interest.

Sample Availability: Samples of the Buddha's hand are available from the authors.

\section{References}

1. Albergamo, A.; Costa, R.; Dugo, G. Cold pressed lemon (Citrus limon) seed oil. In Cold Pressed Oils; Ramadan, M.F., Ed.; Academic Press: New York, NY, USA, 2020; pp. 159-180.

2. Citrus-FAO (Food and Agricultural Organization). Available online: https://www.fao.org/markets-and-trade/commodities/ citrus/en/ (accessed on 22 February 2022).

3. Raghavan, S.; Gurunathan, J. Citrus species-A golden treasure box of metabolites that is beneficial against disorders. J. Herb. Med. 2021, 28, 100438. [CrossRef]

4. Sharma, K.; Mahato, N.; Lee, Y.R. Extraction, characterization and biological activity of citrus flavonoids. Rev. Chem. Eng. 2019, 35, 265-284. [CrossRef]

5. Lv, X.; Zhao, S.; Ning, Z.; Zeng, H.; Shu, Y.; Tao, O.; Xiao, C.; Lu, C.; Liu, Y. Citrus fruits as a treasure trove of active natural metabolites that potentially provide benefits for human health. Chem. Cent. J. 2015, 9, 68. [CrossRef]

6. Bora, H.; Kamle, M.; Mahato, D.K.; Tiwari, P.; Kumar, P. Citrus essential oils (CEOs) and their applications in food: An overview. Plants 2020, 9, 357. [CrossRef] [PubMed]

7. Ali, B.; Al-Wabel, N.A.; Shams, S.; Ahamad, A.; Khan, S.A.; Anwar, F. Essential oils used in aromatherapy: A systemic review. Asian Pac. J. Trop. Biomed. 2015, 5, 601-611. [CrossRef]

8. Flora of China. Available online: http://www.efloras.org/florataxon.aspx?flora_id=2\&taxon_id=200012432 (accessed on 25 January 2022).

9. Mahdi, A.A.; Al-Ansi, W.; Ahmed, M.I.; Wang, H. Bioactive compounds and functional benefits of the Foshou Fruit: A Review. J. Food Nutr. Res. 2018, 6, 486-491. [CrossRef]

10. $\mathrm{Wu}, \mathrm{Z}$. Effect of different drying methods on chemical composition and bioactivity of finger citron polysaccharides. Int. J. Biol. Macromol. 2015, 76, 218-223. [CrossRef]

11. Theanphong, O.; Songsak, T.; Mingvanish, W. Chemical composition and antimicrobial activity of the essential oil from Citrus medica L. var. sarcodactylis (Sieber) Swingle leaf. Mahidol Univ. J. Pharm. Sci. 2008, 35, 57-61.

12. Chan, Y.Y.; Li, C.H.; Shen, Y.C.; Wu, T.S. Anti-inflammatory principles from the stem and root barks of Citrus medica. Chem. Pharm. Bull. 2010, 58, 61-65. [CrossRef]

13. Chan, Y.Y.; Wu, T.S.; Kuo, Y.H. Chemical constituents and cytotoxicity from the stem bark of Citrus medica. Heterocycles 2009, 78, 1309-1316.

14. Peng, C.H.; Ker, Y.B.; Weng, C.F.; Peng, C.C.; Huang, C.N.; Lin, L.Y.; Peng, R.Y. Insulin secretagogue bioactivity of finger citron fruit (Citrus medica L. var. sarcodactylis Hort, Rutaceae). J. Agric. Food Chem. 2009, 57, 8812-8819. [CrossRef]

15. Kim, K.N.; Ko, Y.J.; Yang, H.M.; Ham, Y.M.; Roh, S.W.; Jeon, Y.J.; Ahn, G.; Kang, M.C.; Yoon, W.J.; Kim, D. Antiinflammatory effect of essential oil and its constituents from fingered citron (Citrus medica L. var. sarcodactylis) through blocking JNK, ERK and NF- $\mathrm{B}$ signaling pathways in LPS activated RAW 264.7 cells. Food Chem. Toxicol. 2013, 57, 126-131. [CrossRef] [PubMed]

16. Wu, Z.; Li, H.; Yang, Y.; Zhan, Y.; Tu, D. Variation in the components and antioxidant activity of Citrus medica L. var. sarcodactylis essential oils at different stages of maturity. Ind. Crops Prod. 2013, 46, 311-316. [CrossRef] 
17. Al-Kalifawi, E.J. The antimicrobial activity of essential oils of Al-Abbas's (AS) hand fruit peel (Citrus medica) var. sarcodactylis Swingle. J. Nat. Sci. Res. 2015, 5, 19-27.

18. Zhang, Q.W. Citrus medica L. var. sarcodactylis Swingle (Foshou, Finger Citron). In Dietary Chinese Herbs: Chemistry, Pharmacology and Clinical Evidence; Liu, Y., Wang, Z., Zhang, J., Eds.; Springer: Vienna, Austria, 2015; pp. 327-331.

19. Vitalini, S.; Gardana, C.; Zanzotto, A.; Simonetti, P.; Faoro, F.; Fico, G.; Iriti, M. The presence of melatonin in grapevine (Vitis vinifera L.) berry tissues. J. Pineal Res. 2011, 51, 331-337. [CrossRef] [PubMed]

20. Vitalini, S.; Iriti, M.; Vinciguerra, V.; Garzoli, S. A Comparative study of the chemical composition by SPME-GC/MS and antiradical activity of less common Citrus Species. Molecules 2021, 26, 5378. [CrossRef] [PubMed]

21. Garzoli, S.; Laghezza Masci, V.; Franceschi, S.; Tiezzi, A.; Giacomello, P.; Ovidi, E. Headspace/GC-MS analysis and investigation of antibacterial, antioxidant and cytotoxic activity of essential oils and hydrolates from Rosmarinus officinalis L. and Lavandula angustifolia Miller. Foods 2021, 10, 1768. [CrossRef] [PubMed]

22. Ovidi, E.; Laghezza Masci, V.; Zambelli, M.; Tiezzi, A.; Vitalini, S.; Garzoli, S. Laurus nobilis, Salvia sclarea and Salvia officinalis essential oils and hydrolates: Evaluation of liquid and vapor phase chemical composition and biological activities. Plants 2021, 10, 707. [CrossRef] [PubMed]

23. Garzoli, S.; Laghezza Masci, V.; Ovidi, E.; Turchetti, G.; Zago, D.; Tiezzi, A. Chemical investigation of a biologically active Schinus molle L. leaf extract. J. Anal. Methods Chem. 2019, 2019, 8391263. [CrossRef]

24. Vitalini, S.; Madeo, M.; Tava, A.; Iriti, M.; Vallone, L.; Avato, P.; Cocuzza, C.E.; Simonetti, P.; Argentieri, M.P. Chemical profile, antioxidant and antibacterial activities of Achillea moschata Wulfen, an endemic species from the Alps. Molecules 2016, 21, 830. [CrossRef]

25. Assefa, A.D.; Ko, E.Y.; Moon, S.H.; Keum, Y. Antioxidant and antiplatelet activities of flavonoid-rich fractions of three citrus fruits from Korea. 3 Biotech 2016, 6, 109. [CrossRef] [PubMed]

26. Iriti, M.; Vitalini, S.; Apostolides, N.A.; El Beyrouthy, M. Chemical composition and antiradical capacity of essential oils from Lebanese medicinal plants. J. Essent. Oil Res. 2014, 26, 466-472. [CrossRef]

27. Garzoli, S.; Masci Laghezza, V.; Caradonna, V.; Tiezzi, A.; Giacomello, P.; Ovidi, E. Liquid and Vapor Phase of Four ConiferDerived Essential Oils: Comparison of Chemical Compositions and Antimicrobial and Antioxidant Properties. Pharmaceuticals 2021, 14, 134. [CrossRef] [PubMed]

28. Ovidi, E.; Laghezza Masci, V.; Taddei, A.R.; Paolicelli, P.; Petralito, S.; Trilli, J.; Mastrogiovanni, F.; Tiezzi, A.; Casadei, M.A.; Giacomello, P.; et al. Chemical investigation and screening of anti-proliferative activity on human cell lines of pure and nano-formulated lavandin essential oil. Pharmaceuticals 2020, 13, 352. [CrossRef]

29. Song, S.; Tong, Y.; Feng, T.; Zhu, J. Multi-analysis of Odorous Compounds in Finger Citron (Citrus medica L. var. sarcodactylis Swingle) and Certification of Key Compounds. J. Essent. Oil Bear. Plants 2018, 2, 600-613. [CrossRef]

30. Chen, X.; Chen, H.; Xiao, J.; Liu, J.; Tang, N.; Zhou, A. Variations of volatile flavour compounds in finger citron (Citrus medica L.var. sarcodactylis) pickling process revealed by E-nose, HS-SPME-GC-MS and HS-GC-IMS. Int. Food Res. J. 2020, 138, 109717. [CrossRef]

31. Li, Z.H.; Cai, M.; Liu, Y.S.; Sun, P.L.; Luo, S.L. Antibacterial activity and mechanisms of essential oil from Citrus medica L. var sarcodactylis. Molecules 2019, 24, 1577. [CrossRef]

32. Shiota, H. Volatile components in the peel oil from fingered citron (Citrus medica L. var. sarcodactylis swingle). Flavour Frag. J. 1990, 5, 33-37. [CrossRef]

33. Sayorwan, W.; Rumruay, V. Chemical compositions of fingered citron peel (citrus medica L. var. sarcodactylis) and its effect on the autonomic nervous system. J. Health Res. 2017, 31, 307-313.

34. Dang, N.H.; Nhung, P.H.; Anh, B.T.M.; Thuy, D.T.T.; Minh, C.V.; Dat, N.T. Chemical composition and $\alpha$-glucosidase inhibitory activity of Vietnamese Citrus peels essential oils. J. Chem. 2016, 2016, 6787952. [CrossRef]

35. Gao, Z.; Zhong, W.; Chen, K.; Tang, P.; Gu, J. Chemical composition and anti-biofilm activity of essential oil from Citrus medica L. var. sarcodactylis Swingle against Listeria monocytogenes. Ind. Crops Prod. 2020, 144, 112036. [CrossRef]

36. Luo, C.; Li, D.; Wang, Y.; Guo, S.; Zhang, D.; Du, S. Chemical composition and insecticide efficacy of essential oils from Citrus medica L. var. sarcodactylis Swingle against Tribolium castaneum Herbst in stored medicinal materials. J. Essent. Oil Bear. Plants 2019, 22, 1182-1194. [CrossRef]

37. Deng, G.; Craft, J.D.; Steinberg, K.M.; Li, P.L.; Pokharel, S.K.; Setzer, W.N. Influence of different isolation methods on chemical composition and bioactivities of the fruit peel oil of Citrus medica L. var. sarcodactylis (Noot.) Swingle. Medicines 2017, 4, 1. [CrossRef]

38. Tava, A.; Iriti, M.; Vitalini, S. Composition and antioxidant activity of the essential oil from Achillea moschata Wulfen growing in Valchiavenna and Valmalenco (Italian Central Alps). Int. J. Hort. Sci. Technol. 2020, 7, 335-341.

39. Xu, Y.Q.; Ji, W.B.; Yu, P.; Chen, J.X.; Wang, F.; Yin, J.F. Effect of extraction methods on the chemical components and taste quality of green tea extract. Food Chem. 2018, 15, 146-154. [CrossRef] [PubMed]

40. Wang, L.M.; Li, M.T.; Jin, W.W.; Li, S.; Zhang, S.Q.; Yu, L.J. Variations in the components of Osmanthus fragrans Lour. essential oil at different stages of flowering. Food Chem. 2009, 114, 233-236. [CrossRef]

41. Hosni, K.; Zahed, N.; Chrif, R.; Abid, I.; Medfei, W.; Kallel, M.; Brahim, N.B.; Sebei, H. Composition of peel essential oils from four selected tunisian Citrus Species: Evidence for the genotypic influence. Food Chem. 2010, 123, 1098-1104. [CrossRef]

42. Tsao, R. Chemistry and biochemistry of dietary polyphenols. Nutrients 2010, 2, 1231-1246. [CrossRef] 
43. Bouarab-Chibane, L.; Forquet, V.; Lanteri, P.; Clement, Y.; Léonard-Akkari, L.; Oulahal, N.; Degraeve, P.; Bordes, C. Antibacterial properties of polyphenols: Characterization and QSAR (Quantitative Structure-Activity Relationship) models. Front. Microbiol. 2019, 10, 829. [CrossRef]

44. Chen, W.R.; Zheng, J.S.; Li, Y.Q.; Guo, W.D. Effects of high temperature on photosynthesis, chlorophyll fluorescence, chloroplast ultrastructure, and antioxidant activities in fingered citron. Russ. J. Plant Physiol. 2012, 59, 732-740. [CrossRef]

45. Guo, J.-j.; Gao, Z.-p.; Xia, J.-1.; Ritenour, M.A.; Li, G.-y.; Shan, Y. Comparative analysis of chemical composition, antimicrobial and antioxidant activity of citrus essential oils from the main cultivated varieties in China. LWT 2018, 97, 825-839. [CrossRef]

46. Lou, Z.; Chen, J.; Yu, F.; Wang, H.; Kou, X.; Ma, C.; Zhu, S. The antioxidant, antibacterial, antibiofilm activity of essential oil from Citrus medica L. var. sarcodactylis and its nanoemulsion. LWT 2017, 80, 371-377. [CrossRef]

47. Mahdi, A.A.; Al-Ansi, W.; Ahmed, M.I.; Xiaoyun, C.; Mohammed, J.K.; Sulieman, A.A.; Sajid, B.; Harimana, Y.; Wang, H. Microwave assisted extraction of the bioactive compounds from peel/pulp of Citrus medica L. var. sarcodactylis swingle along with its nutritional profiling. J. Food Meas. Charact. 2020, 14, 283-292. [CrossRef]

48. Böhme, K.; Barros-Velázquez, J.; Calo-Mata, P.; Aubourg, S.P. Antibacterial, antiviral and antifungal activity of essential oils: Mechanisms and applications. In Antimicrobial Compounds; Villa, T., Veiga-Crespo, P., Eds.; Springer: Berlin/Heidelberg, Germany, 2014; pp. 51-81.

49. Wińska, K.; Mączka, W.; Łyczko, J.; Grabarczyk, M.; Czubaszek, A.; Szumny, A. Essential oils as antimicrobial agents-myth or real alternative? Molecules 2019, 24, 2130. [CrossRef] [PubMed]

50. Mutlu-Ingok, A.; Devecioglu, D.; Dikmetas, D.N.; Karbancioglu-Guler, F.; Capanoglu, E. Antibacterial, antifungal, antimycotoxigenic, and antioxidant activities of essential oils: An updated review. Molecules 2020, 25, 4711. [CrossRef] [PubMed]

51. Sahoo, C.R.; Sahoo, J.; Mahapatra, M.; Lenka, D.; Sahu, K.P.; Dehury, B.; Padhy, R.N.; Paidesetty, S.K. Coumarin derivatives as promising antibacterial agent(s). Arab. J. Chem. 2021, 14, 102922. [CrossRef]

52. Wang, F.; You, H.; Guo, Y.; Wei, Y.; Xia, P.; Yang, Z.; Ren, M.; Guo, H.; Han, R.; Yang, D. Essential oils from three kinds of fingered citrons and their antibacterial activities. Ind. Crops Prod. 2020, 147, 112172. [CrossRef]

53. Gupta, A.; Jeyakumar, E.; Lawrence, R. Strategic approach of multifaceted antibacterial mechanism of limonene traced in Escherichia coli. Sci. Rep. 2021, 11, 13816. [CrossRef]

54. Han, Y.; Sun, Z.; Chen, W. Antimicrobial Susceptibility and Antibacterial Mechanism of Limonene against Listeria monocytogenes. Molecules 2020, 25, 33. [CrossRef]

55. Pathirana, H.N.; Wimalasena, S.H.; De Silva, B.C.; Hossain, S.; Heo, G.J. Antibacterial activity of lime (Citrus aurantifolia) essential oil and limonene against fish pathogenic bacteria isolated from cultured olive flounder (Paralichthys olivaceus). Fish. Aquat. Sci. 2018, 26, 131-139. [CrossRef]

56. Oyedemi, S.O.; Okoh, A.I.; Mabinya, L.V.; Pirochenva, G.; Afolayan, A.J. The proposed mechanism of bactericidal action of eugenol, $\alpha$-terpineol and $\gamma$-terpinene against Listeria monocytogenes, Streptococcus pyogenes, Proteus vulgaris and Escherichia coli. J. Appl. Bacteriol. 2009, 8, 1280-1286.

57. Akkol, E.K.; Genç, Y.; Karpuz, B.; Sobarzo-Sánchez, E.; Capasso, R. Coumarins and coumarin-related compounds in pharmacotherapy of cancer. Cancers 2017, 12, 1959. [CrossRef] [PubMed]

58. Wu, Y.; Xu, J.; Liu, Y.; Zeng, Y.; Wu, G. A review on anti-tumor mechanisms of coumarins. Front. Oncol. 2020, 10, 2720. [CrossRef] [PubMed]

59. Hou, Y.; Wang, Y.; Zheng, C.; Feng, K. Biotransformation of 5-hydroxymethylfurfural into 2,5-dihydroxymethylfuran by Ganoderma sessile and toxicological assessment of both compounds. AMB Expr. 2020, 10, 1-11. [CrossRef] [PubMed]

60. Li, Y.X.; Li, Y.; Qian, Z.J.; Kim, M.M.; Kim, S.K. In vitro antioxidant activity of 5-HMF isolated from marine red alga Laurencia undulata in free radical mediated oxidative systems. J. Microbiol. Biotechnol. 2009, 19, 1319-1327. [CrossRef] [PubMed]

61. Fairlamb, I.J.S.; Lester, R.; Marrison, L.R.; Dickinson, J.M.; Lu, F.J.; Schmidt, J.P. 2-Pyrones possessing antimicrobial and cytotoxic activities. Bioorg. Med. Chem. 2004, 12, 4285-4299. [CrossRef]

62. Merkle, S.; Kleeberg, K.K.; Fritsche, J. Recent Developments and Applications of Solid Phase Microextraction (SPME) in Food and Environmental Analysis-A Review. Chromatography 2015, 2, 293-381. [CrossRef]

63. Ribeiro, S.O.; Fontaine, V.; Mathieu, V.; Zhiri, A.; Baudoux, D.; Stévigny, C.; Souard, F. Antibacterial and Cytotoxic Activities of Ten Commercially Available Essential Oils. Antibiotics 2020, 9, 717. [CrossRef]

64. Taib, M.; Rezzak, Y.; Bouyazza, L.; Lyoussi, B. Medicinal Uses, Phytochemistry, and Pharmacological Activities of Quercus Species. Evid. Based Complement. Altern. Med. 2020, 2020, 1920683. [CrossRef]

65. Jakubczyk, K.; Tuchowska, A.; Janda-Milczarek, K. Plant hydrolates-Antioxidant properties, chemical composition and potential applications. Biomed. Pharmacother. 2021, 142, 112033. [CrossRef]

66. Mitropoulou, G.; Fitsiou, E.; Spyridopoulou, K.; Tiptiri-Kourpeti, A.; Bardouki, H.; Vamvakias, M.; Panas, P.; Chlichlia, K.; Pappa, A.; Kourkoutas, Y. Citrus medica essential oil exhibits significant antimicrobial and antiproliferative activity. LWT 2017, 84, 344-352. [CrossRef]

67. Laghezza Masci, V.; Ovidi, E.; Taddei, A.R.; Turchetti, G.; Tiezzi, A.; Giacomello, P.; Garzoli, S. Apoptotic effects on HL60 human leukaemia cells induced by lavandin essential oil treatment. Molecules 2020, 25, 538. [CrossRef] [PubMed]

68. Khaleel, C.; Tabanca, N.; Buchbauer, G. $\alpha$-Terpineol, a natural monoterpene: A review of its biological properties. Open Chem. 2018, 16, 349-361. [CrossRef] 